\title{
Prevalence, Bacterial Association and In Vitro Antimicrobials Susceptibility of Subclinical Mastitis in Crossbred Cows
}

\author{
Srijit Tripathi $^{1}$, Niddhi Arora ${ }^{1}$, S. Shekhar ${ }^{2 *}$ and V.S. Rajora ${ }^{1}$ \\ ${ }^{1}$ Department of Veterinary Medicine, C.V.A.Sc., G. B. P. U. A. T., Pantnagar, Uttarakhand, India \\ ${ }^{2}$ Krishi Vigyan Kendra (ICAR-NRRI), Koderma, Jharkhand, India \\ *Corresponding author
}

\section{A B S T R A C T}

\begin{tabular}{|c|c|}
\hline Keywords & $\begin{array}{l}\text { The subclinical mastitis is a more serious concern and is responsible for much } \\
\text { greater losses to the dairy industry in India. The prevalence of subclinical mastitis }\end{array}$ \\
\hline $\begin{array}{l}\text { Bacteria, CMT, } \\
\text { Prevalence, SCM, } \\
\text { Quarter, Parity, } \\
\text { Enrofloxacin. }\end{array}$ & $\begin{array}{l}\text { (SCM) was recorded }(56.25 \%) \text { in cross breed cow, with higher involvement } \\
(33.17 \%) \text { of right hindquarters. The prevalence was also found highest }(19.04 \%) \\
\text { in third parity and early stage }(41.26 \%) \text { of lactation. Microbiological examination }\end{array}$ \\
\hline Article Info & followed by Streptococcus spp. $(23.23 \%)$, E. Coli $(02.81 \%)$ and mixed infection \\
\hline $\begin{array}{l}\text { Accepted: } \\
\text { 23 September } 2017 \\
\text { Available Online: } \\
10 \text { October } 2017\end{array}$ & $\begin{array}{l}(07.04 \%) \text {. Enrofloxacin was found to be the most effective antibiotic against } \\
\text { SCM. For early detection of subclinical mastitis, CMT can be performed regularly } \\
\text { as a control measure and emphasis should be given on farm management } \\
\text { practices, particularly on milking procedure and udder sanitation. }\end{array}$ \\
\hline
\end{tabular}

\section{Introduction}

Bovine mastitis is the one of the most prevalent disease of the dairy industry throughout the world. The sub clinical form of mastitis is characterized by having no visible sign either in the udder or in the milk but a negative relationship exists between somatic cell counts (SCC) and the milk yield has been reported (Khan and Khan, 2006). Subclinical Mastitis (SCM) is more important due to the fact that it is $15-40$ times more prevalent as compared to the clinical mastitis, it usually precedes the clinical form, is of longer duration, difficult to detect, adversely affects milk quality and production and constitutes a reservoir of microorganisms that lead to infection of other animals within the herd (Shearer and Harris, 2003). The pattern of causative agents and disease prevalence markedly differ from place to place, herd to herd and time to time. It is recognized as one of the most costly diseases with annual losses in the dairy industry touching approximately 2 billion dollars in USA.

In India the losses are estimated to be about Rs. 7,165 crores that include Rs. 4151.16 crores and Rs. 3014.35 crores due to subclinical mastitis and clinical mastitis, respectively (Bansal and Gupta, 2009) and in a crossbred cow Rs. 1, 314.10 (Singh et al., 2014). The present investigation was therefore envisaged with the objective of 
screening of the crossbred cows of subclinical mastitis at I.D.F. Pantnagar by using field diagnostic test i.e. California mastitis test.

\section{Materials and Methods}

112 lactating crossbred cows at Instructional Dairy farm (IDF), G.B. Pant University of Agriculture and Technology, Pantnagar, Uttarakhand were screened for SCM using California Mastitis Test (CMT).

The milk samples (about 10 to $15 \mathrm{ml}$ ) from individual quarter were collected in sterilized test tubes after cleaning the teat orifice with $70 \%$ ethyl alcohol and after discarding the first few streams of milk.

California mastitis test was conducted and interpreted as per standard method described by Pandit and Mehta (1969).

The results were read as negative (-), trace, one plus (+), two plus (++) and three plus $(+++)$ depending upon the degree of gel formation and graded as $0,1,2,3$ and 4, respectively.

The prevalence of subclinical mastitis were estimated as overall, quarter wise, age wise (less than 5 years, 5 to 8 years and more than 8 years of age), parity wise, lactation stage wise i.e. early ( $<60$ days post parturition), mid (60-90 days post parturition) or late (>90days post parturition) and Lactation yield wise viz. high $(>12 \mathrm{~L})$, average $(5-8 \mathrm{~L})$ and low $(<5 \mathrm{~L})$ milk yielders.

The different milk samples were analyzed for bacterial investigation viz. Staphylococcus aureus, Sreptococcus agalactiae, E. coli and mixed infection in positive cases of subclinical mastitis. The sensitivity and resistance patterns of different bacteria's against the different antibiotics were performed using Kirby -Bauer discs.

\section{Results and Discussion}

Out of 112 crossbred cows studied, 63 were positive for subclinical mastitis. Among a total of 428 quarters, 142 quarters were found positive for subclinical mastitis. The overall and quarter wise prevalence of subclinical mastitis was computed to be $56.25 \%$ and $33.17 \%$ respectively (Table 1 ) which was in agreement to the findings of Gupta (2010) who found an overall prevalence of subclinical mastitis as $57.72 \%$ and quarter wise prevalence as $32.98 \%$. In the individual quarter wise prevalence study (Table 1), the highest prevalence was in right hind quarters $(43.80 \%)$ followed by left hind quarters (43.68\%), left fore quarters $(23.85 \%)$ and right fore quarters $(22.52 \%)$ which is in very close agreement to Kumar (2010). The probable reason for more involvement of hind quarters might be the frequent exposure of rear teat tips to urine and dung during their excretion. Study also revealed that out of 20 $(4.67 \%)$ blind quarters, $4(20.00 \%)$ were left fore, $5(25.00 \%)$ were right fore, $6(30.00 \%)$ were left hind and $8(40.00 \%)$ were right hind quarters. It might be due to their more susceptibility for mastitis. The findings of the study are in agreement with the findings of Khan and Muhammad (2005) who also reported that the prevalence of blind quarters in cows was higher in hindquarters as compared to the forequarters and slightly higher in right quarters than left ones. Prevalence of subclinical mastitis was $36.50 \%$, $47.61 \%$ and $15.87 \%$ in the age groups of $<5$ years, $5-8$ years and $>8$ years respectively, which was very much in accordance to the findings of Islam et al., (2011) who found the prevalence of subclinical mastitis as $33.33 \%, 40.90 \%$, $28.57 \%$ and $0.00 \%$ respectively in the age group of 3 years to 5 years, 5 years to 8 years, 8 years to 12 years and $>12$ years in cross breed cows. The weak immune system with age could probably be considered as the 
reason behind this relationship of age with the increasing incidence of subclinical mastitis in crossbred cows. The highest number of subclinical mastitis cases were detected in cows between third to fifth parity $(52.38 \%)$ followed by cows of first and second parity $(38.09 \%)$ and cows in sixth parity or above $(15.87 \%)$, which is in close agreement to Gupta (2010). The possible reason for the highest incidence during third, fourth or fifth lactation may be the decreased resistance of animals and reduced effectiveness of streak canal as a barrier of infection with increasing lactation age (Nauriyal, 1996). Highest prevalence of subclinical mastitis was seen in the animals in early period of lactation $(41.26 \%)$ followed by mid $(33.33 \%)$ and late (25.39\%) lactation periods. The present findings were in corroboration with the findings of Kumar (2010) who recorded maximum subclinical mastitis cases in cows between 31-60 days after parturition followed by 60-90 days of lactation period. This could be due to the fact that in early stage of lactation cows are under stress due to parturition causing decreased resistance (Houben et al., 1993).

Erskine et al., (1988) opined that most new infections occur in the first 2 months of lactation, especially the environmental infections. The prevalence of subclinical mastitis recorded was $20.63 \%, 30.15 \%$, and $49.20 \%$ in lactating cows with daily milk yield of $5-8 \mathrm{~L}, 8-12 \mathrm{~L}$ and more than 12L, respectively. Kayesh et al., (2014) found that the highest prevalence of subclinical mastitis based on daily milk yield was $71.43 \%$ found in the cattle producing milk within a range of 5-7L and cows with a daily milk yield of 3-5L and $5-7 \mathrm{~L}$ had significantly $(\mathrm{p}<0.05)$ higher prevalence of subclinical mastitis. The prevalence of subclinical mastitis in crossbred cows were $28.57 \%, 35.48 \%, 40.00 \%$ and $42.85 \%$, respectively $1-2 \mathrm{~L}, 2-5 \mathrm{~L}, 5-10 \mathrm{~L}$ and 10L milk production per day (Islam et al.,
2011). The probable reason of increased chances of SCM in high yielders may be their increased susceptibility for the infections. Cattle producing high quantity of milk are susceptible for intramammary infection and there was rising trend of subclinical mastitis as reviewed by Radostits et al., (2005). Out of total 142 positive samples, 95 (66.90\%) samples were found positive for Staphylococcus spp. followed by Streptococcus spp 33 (23.23\%).E. coli 04 $(02.81 \%)$ and mixed infection $10(07.04 \%)$. Patel et al., (2012) found that the most prevalent pathogen isolated from 235 milk samples was Staphylococcus aureus 72 (30.64\%), followed by Streptococcus agalactiae 47 (20.00\%), E. coli $24(10.21 \%)$, Pseudomonas 22 (9.36\%), Proteus 6 (2.55\%), Pasteurella 6 (2.55\%), Salmonella 4 (1.70\%) and mixed growth 54 (22.98\%). Such a high involvement of Staphylococcus spp. observed during present investigation would be attributed to the ability of the bacteria to colonize on the teat ends and teat canal weeks before invading the upper parts of mammary gland and to their survival on the skin for longer period causing new intramammary infection of subclinical in nature (Eberhart et al., 1982).

Quarter wise highest (31.57\%) infection of Staphylococcus spp. was observed in right hind quarter followed by left hind quarters (29.47\%), right fore quarters $(20.00 \%)$ and left fore quarters (18.94\%). Streptococcus spp. infection was found maximum (36.36\%) in left hind quarter followed by right hind quarters $(33.33 \%)$, and left fore quarters (18.18\%) and right fore quarters (12.12\%). Two cases $(50 \%)$ of $E$. coli were seen in right hind quarter while one case each was seen in both left hind and right front quarter. Mixed infection was recorded greatest $(40.00 \%)$ in left hind quarter (Table 2). All these findings are in close agreement to the findings of Kumar (2010). 
Table.1 Overall and quarter wise prevalence of subclinical mastitis affected cows

\begin{tabular}{|l|l|l|l|l|l|l|}
\hline \multirow{2}{*}{ Observations } & \multirow{2}{*}{$\begin{array}{l}\text { No. of } \\
\text { animals }\end{array}$} & $\begin{array}{l}\text { Total No. of } \\
\text { functional } \\
\text { quarters } \\
\text { examined }\end{array}$ & \multicolumn{2}{l}{ Quarter wise prevalence } \\
\cline { 5 - 7 } & & LF & RF & LH & RH \\
\hline Cows examined & 112 & 428 & 109 & 111 & 103 & 105 \\
\hline SCM positive & 63 & 142 & 26 & 25 & 45 & 46 \\
\hline Prevalence (\%) & 56.25 & 33.17 & 23.85 & 22.52 & 43.68 & 43.80 \\
\hline
\end{tabular}

Table.2 Quarter wise association of bacteria in subclinical mastitis affected cows

\begin{tabular}{|l|l|l|l|l|l|}
\hline \multirow{2}{*}{ Bacteria } & \multicolumn{4}{|c|}{ Quarter affected } & \multirow{2}{*}{ Total } \\
\cline { 2 - 6 } & RF & LF & RH & LH & $95(66.90 \%)$ \\
\hline $\begin{array}{l}\text { Staphylococcus } \\
\text { spp. }\end{array}$ & $19(20 \%)$ & $18(18.94 \%)$ & $30(31.57 \%)$ & $28(29.47 \%)$ & \\
\hline $\begin{array}{l}\text { Streptococcus } \\
\text { spp. }\end{array}$ & $4(12.12 \%)$ & $6(18.18 \%)$ & $11(33.33 \%)$ & $12(36.36 \%)$ & $33(23.23 \%)$ \\
\hline E. coli & $1(25 \%)$ & $0(0 \%)$ & $2(50 \%)$ & $1(25 \%)$ & $4(2.81 \%)$ \\
\hline Mixed infection & $1(10 \%)$ & $2(20 \%)$ & $3(30 \%)$ & $4(40 \%)$ & $10(7.04)$ \\
\hline
\end{tabular}

During the investigation, Staphylococcus spp. exhibited reasonably higher sensitivity to enrofloxacin, cefotaxime, gentamicin, amikacin, and choramphenicol, and moderate to amoxicillin, ampicillin, erythromycin, streptomycin. Streptococcus spp. showed higher sensitivity to cefotaxime and enrofloxacin and moderate to amoxicillin, choramphenicol and gentamicin and least to streptomycin. E. coli showed higher sensitivity to cefotaxime, enrofloxacin, amikacin and moderate to amoxicillin, gentamicin and low to choramphenicol. Mixed infection had higher sensitivity to enrofloxacin and cefotaxime, and moderate to gentamicin, tetracycline, choramphenicol, and least sensitive with ampicillin and amoxicillin. Enrofloxacin was found to be the most effective antibiotic against SCM in the present study. Sharma (2000) also reported highest in-vitro sensitivity of enrofloxacin (93.07\%) followed by cloxacillin (64.61\%) against microbes associated with mastitis in Himachal Pradesh. The sensitivity pattern would vary depending on the intensive use of antibiotics in particular region for therapeutic uses in livestock. Enrofloxacin which has been developed for exclusive use in veterinary practice, belonged to fluoroquinolones, is a potent synthetic antimicrobial agent with long lasting bactericidal effect with extended spectrum of antibacterial activity (Neer, 1998). Some mastitis pathogens exhibited poor sensitivity to certain antimicrobials and this can be attributed to indiscriminate and prolonged use of antibacterial drugs in the absence of in vitro drug susceptibility testing of mastitis pathogens as has earlier been reported by Sobiraj et al., (1999).

\section{References}

Atasever, S., 2012. Estimation of correlation between somatic cell count and coagulation score of bovine milk. Int. J. Agr. Biol. 14: 315-317.

Bansal, B. K., and Gupta, D. K. 2009. Economic analysis of Bovine mastitis in India and Punjab- A review. Indian J. Dairy Sci. 62: $337-345$. 
Eberhart, R. J., 1982. Coliform mastitis. Veterinary Clinics North America; Large Anim. Pract. 6: 287-300.

Erskine, R. J., Eberhart, R. J., Hutchinson, L. J. and Spencer, S. B. 1986. Incidence and types of clinical mastitis associated with high and low cell count dairy herds. J. Dairy Sci. 69: 101.

Gupta, D., 2010. Evaluation of Immunetherapeutic and Antioxidative effect of some herbs in bovine subclinical mastitis. Thesis, Ph.D. G. B. Pant University of Agriculture and Technology, Pantnagar (India).

Houben, E. H. P., Dijkhuizen, A. A., Arendonk, J. V., Huirne, R. B. M. and Van, A. J. 1993. Short and long term production losses and repeatability of clinical mastitis in dairy cattle. J. Dairy Sci. 76: 2561-2578.

Islam, M. A., Islam, M. Z., Islam M. A., Rahman, M. T. and Islam, M. T. 2011. Prevalence of subclinical mastitis in dairy cows in selected areas of Bangladesh. Bangl. J. Vet. Med. 9 (1):73-78.

Kayesh, M. E. H., Talukder. M. and Anower A. K. M. M. 2014. Prevalence of subclinical mastitis and its association with bacteria and risk factors in lactating cows of Barisal district in Bangladesh. Int. J. Biol. Res. 2 (2): 35-38.

Khan, A. Z., and Muhammad, G. 2005. Quarterwise comparative prevalence of mastitis in buffaloes and crossbred cows. Pakistan Vet. J. 25(1): 9-11.

Khan, M. Z., and Khan, A. 2006. Basic facts of mastitis in dairy animals: A review Pakistan Vet. J. 26 (4): 204-208.

Kumar, S., 2010. Development of herbal remedies for management of subclinical mastitis in bovines. Thesis, M.V.Sc. G. B. Pant University of Agriculture and Technology, Pantnagar (India). 59 p.
Nauriyal, D. S., 1996. Profile studies in bovine mastitis with special reference to therapeutic consideration of Vit. E and Selenium. Thesis, Ph.D. G. B. Pant University of Agriculture and Technology, Pantnagar. $56 \mathrm{p}$.

Neer, T. M. C., 1998. Clinical pharmacological features of fluoroquinolone antimicrobial drugs. J. Am. Vet. Med. Assoc. 193: 577-580.

Pandit, A. V., and Mehta, M. L. 1969. Sodium Lauryl Sulphate as a substitute for CMT reagent (California Mastitis test Reagent) for diagnosis of sub clinical mastitis in buffaloes. Indian Vet. J. 46: 111-19.

Patel, J. V., Bhingaradia, B. V., Patel, B. B., Patel, S. B., Patel, P. B., Vahora, S. P. 2012. Study on Prevalence of Mastitis and Antibiotic Sensitivity of Bacterial Isolates Recovered from Crossbred Cows of Anand District of Gujarat Indian J. Dairy Sci. 65(6):467-471.

Radostits, O. M., Gay, C. C., Blood, D. C. and Hinchcliff, K. W. 2005. A Text Book of the Disease of Cattle, Sheep, Pigs, Goats and Horses. $9^{\text {th }}$ Ed. New York: W.B. Sounders Company Ltd. 603-687 p.

Sharma, A. K., 2000. Studies on prevalence and therapeutics of mastitis in dairy animals. M.V.Sc. Thesis. H.P.K.V. Palampur (H.P.). $61 \mathrm{p}$.

Shearer, J. K., and Harris, B. 2003. Mastitis in dairy goats. Anim. Sci. Dept. Florida Coop. Ext. Serv. Inst. Food Agri. Sci; Univ. Fl. Gainesville, USA. pp: 1-6.

Sobiraj, A., Kran, A., Sahollmeyer, V. and Failing, K. 1999. An investigation into the in vitro resistence to antibiotics of pathogenic bacteria in the milk of dairy cows with subclinical mastitis and the distribution of these bacteria in Germany. Tierarztllchepraxin. 25 : $108-115$.

\section{How to cite this article:}

Srijit Tripathi, Niddhi Arora, S. Shekhar and Rajora, V.S. 2017. Prevalence, Bacterial Association and In Vitro Antimicrobials Susceptibility of Subclinical Mastitis in Crossbred Cows. Int.J.Curr.Microbiol.App.Sci. 6(10): 2722-2726.

doi: https://doi.org/10.20546/ijcmas.2017.610.320 